\title{
PENGEMBANGAN MOBILE LEARNING BERBASIS ANDROID SEBAGAI SARANA BERLATIH MENGERJAKAN SOAL MATEMATIKA
}

\author{
Danang Setyadi \\ danang.setyadi@staff.uksw.edu \\ Program Studi Pendidikan Matematika \\ FKIP-Universitas Kristen Satya Wacana
}

\begin{abstract}
ABSTRAK
Penelitian ini bertujuan untuk mengembangkan mobile learning yang berupa game quiz berbasis android pada materi barisan dan deret. Penelitian ini adalah penelitian pengembangan. Prosedur dalam penelitian ini terdiri dari analisis produk yang dikembangkan, mengembangkan produk awal, dan uji coba produk. Hasil penelitian menunjukkan bahwa game quiz berbasis android yang dikembangkan valid. Hasil validasi media sebesar 3,43 dan validasi materi sebesar 3,57. Hasil uji coba produk menunjukkan bahwa game quiz berbasis android yang dikembangkan mampu memotivasi siswa dalam berlatih mengerjakan soal matematika.
\end{abstract}

Kata Kunci: mobile learning, android, dan matematika

\section{PENDAHULUAN}

Keberhasilan siswa dalam belajar matematika dipengaruhi oleh berbagai faktor. Faktor-faktor tersebut antara lain minat siswa, motivasi siswa, inteligensi siswa, sikap siswa, lingkungan sosial, pendekatan yang dilakukan oleh guru, dan metode yang digunakan oleh guru (Hasmiah, 2010; Syah, 2010). Faktor lain yang juga berpengaruh adalah media pembelajaran.

Media pembelajaran merupakan alat yang dapat menyampaikan atau mengantarkan pesan-pesan pembelajaran (Arsyad, 2015:3). Penggunaan media pembelajaran yang menarik akan meningkatkan motivasi dan minat siswa untuk belajar yang pada akhirnya akan membuat siswa berhasil memahami materi yang diberikan (Setyadi dan Qohar, 2017:1).

Seiring berkembangnya teknologi, perkembangan media pembelajaran dalam pembelajaran matematika juga menghasilkan berbagai media yang beragam. Salah satu media tersebut adalah mobile learning. Secara sederhana, mobile learning dapat diartikan sebagai media pembelajaran yang memungkinkan siswa untuk belajar dimanapun mereka berada.

Penggunaan mobile learning dalam pembelajaran matematika memiliki beberapa keunggulan, diantaranya 1) dapat dioperasikan dimanapun dan kapanpun, 2) meningkatkan motivasi siswa, dan 3) meningkatkan pembelajaran sesuai kebutuhan siswa.

Pengembangan mobile learning sebagai media pembelajaran matematika telah dilakukan oleh beberapa peneliti, diantaranya oleh Purbasari (2013) dan Kusuma (2016) yang mengembangkan mobile learning berbasis android. Hasil pengembangan yang dilakukan oleh kedua peneliti tersebut menunjukkan bahwa media yang dikembangkan lebih cenderung memfokuskan pada materi ajarnya saja. Mobile learning yang dikembangkan belum difokuskan sebagai sarana berlatih mengerjakan soal matematika yang dapat memberikan berbagai jenis soal 
yang bervariasi dan menantang. Berdasarkan hal tersebut, peneliti melakukan penelitian dengan judul pengembangan mobile learning berbasis android sebagai sarana berlatih mengerjakan soal matematika.

\section{KAJIAN PUSTAKA}

\section{Media Pembelajaran}

Kata media berasal dari bahasa Latin medius yang secara harafiah berarti 'tengah', 'perantara' atau 'pengantar'. Dalam proses belajar mengajar, media dapat diartikan sebagai alat-alat grafis, photografis, atau elektronis untuk menangkap, memproses, dan menyusun kembali informasi visual atau verbal (Arsyad, 2015:3).

Penggunaan media pembelajaran dalam proses belajar mengajar memiliki beberapa manfaat (Sudjana dan Rivai, 1992: 2; Hamalik, 1994; Arsyad, 2015:29). Secara umum, manfaat penggunaan media pembelajaran adalah: 1) memperjelas penyajian pesan dan informasi 2) meningkatkan motivasi belajar siswa, dan 3) dapat mengatasi keterbatasan indera, ruang, dan waktu.

\section{Mobile Learning}

Mobile learning dapat diartikan sebagai suatu fasilitas yang memberikan informasi elektronik secara umum kepada pembelajar dan content yang edukasional yang membantu mencapai pengetahuan tanpa mempersalahkan lokasi dan waktu (Arifpurnamaya, 2012). Mobile learning merupakan bagian dari e-Learning yang lebih condong kepada pemanfaatan kecanggihan telepon seluler. Mobile learning menyediakan materi pelajaran yang dapat diakses dimana saja dan kapan saja dengan tampilan yang menarik (Fatmawati, 2015:15).
Penggunaan mobile learning akan meningkatkan motivasi belajar siswa dan perhatian siswa dalam belajar matematika. Selain itu, dibandingkan pembelajaran konvensional, mobile learning memungkinkan adanya lebih banyak kesempatan untuk kolaborasi secara langsung dan berinteraksi secara informal di antara siswa (Fatmawati, 2015:16).

\section{Android}

Android merupakan salah satu sistem operasi (OS) untuk smartphone atau tablet yang berbasis Linux (Huda, 2013:1). Pada saat ini, android mempunyai jumlah pengguna paling besar karena memiliki beberapa keunggulan dalam sistem operasinya (Maulana, 2017:198).

Android merupakan sistem operasi yang tepat digunakan untuk pengembangan mobile learning. Hal ini karena android bersifat open source dan dapat diinstal dengan mudah disetiap perangkat yang kompatible.

\section{METODE PENELITIAN}

Penelitian ini merupakan penelitian pengembangan. Mobile learning yang berupa game kuis berbasis Android dikembangkan dengan model pengembangan Borg \& Gall yang dimodifikasi oleh Soenarto (2003) yang terdiri dari tiga tahap, yaitu analisis produk yang dikembangkan, mengembangkan produk awal, dan uji coba produk. Uji coba produk dalam penelitian ini terdiri dari validasi ahli dan revisi serta uji coba skala besar. Uji ahli terdiri dari validasi media dan validasi materi yang dilakukan dengan bantuan dua orang validator, yaitu dosen pendidikan matematika dan guru bidang studi matematika. Uji coba skala besar dilakukan dengan subjek sebanyak 75 siswa SMA di kota Malang. 


\section{HASIL PENGEMBANGAN}

\section{Analisis Produk yang dikembangkan}

Analisis produk yang dikembangkan terdiri dari analisis konsep (concept), analisis desain (design), dan pengumpulan bahan (collecting materials). Pada tahap analisis konsep, dilakukan analisis terhadap hal-hal yang diperlukan dalam perencanaan perangkat pembelajaran. Pada tahap ini, diputuskan bahwa materi yang digunakan adalah barisan dan deret. Materi barisan dan deret dipilih karena materi ini lebih bersifat induktif di dalam pengerjaannya.

Pada tahap analisis desain, peneliti membuat rancangan tentang tampilan game quiz yang akan dikembangkan. Pada tahap ini, peneliti mulai memikirkan tentang menumenu dalam game, tema dan latar belakang game, tata letak, bahasa yang digunakan, dan lainnya.

Pada tahap pengumpulan bahan (collecting materials), dilakukan pengumpulan bahan yang diperlukan untuk membuat produk. Pada tahap ini, peneliti membuat soal dan kunci jawaban yang nantinya akan digunakan sebagai daftar pertanyaan dalam produk yang dikembangkan.

\section{Mengembangkan Produk Awal}

Mengembangkan produk awal diawali dengan menentukan nama game dan selanjutnya membuat game sesuai dengan rancangan yang telah ditetapkan. Hasil pengembangan tersebut adalah sebagai berikut.

Nama game yang telah dikembangkan adalah JeniusMath. Nama ini dipilih karena game android yang dikembangkan berbentuk kuis yang berisi soal matematika dan diharapkan dapat membuat siswa menjadi lebih berhasil dalam belajar matematika.
Game ini terdiri dari 10 soal matematika yang ditulis dalam bahasa inggris. Tampilan awal ketika membuka game android tersebut adalah sebagai berikut.

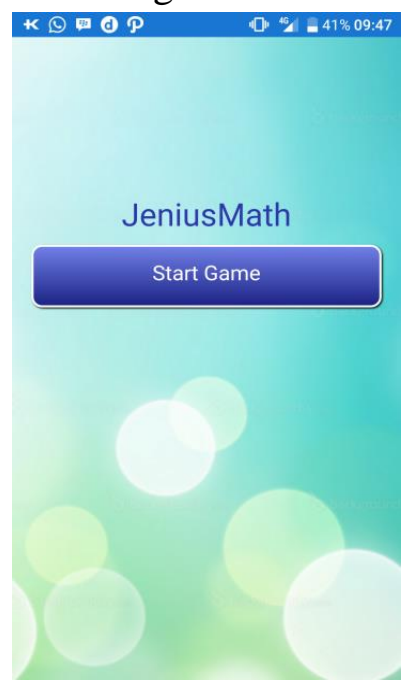

Gambar 1 Tampilan Awal Game

Berdasarkan Gambar 1 di atas, terlihat bahwa halaman awal terdiri dari satu tombol start dan nama game tersebut.

Apabila tombol start tersebut dipilih, pemain akan diarahkan ke pertanyaan yang pertama. Pertanyaan tersebut memberikan empat alternatif pilihan jawaban yang harus dipilih oleh pemain. Berikut adalah gambar yang menunjukkan hal tersebut.

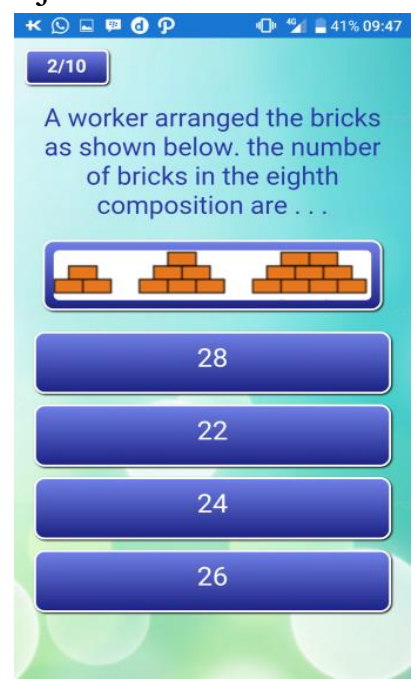

Gambar 2 Tampilan Pertanyaan dan Pilihan Jawaban 
Ketika pemain sudah berhasil menemukan jawaban yang menurutnya tepat, ia dapat memilih salah satu jawaban. Setelah memilih jawaban tersebut, akan ada pemberitahuan apakah jawaban yang ia pilih benar atau tidak. Apabila jawaban yang dipilihnya tepat akan muncul kalimat "your answer is correct" dengan latar belakang tulisan warna hijau sedangkan apabila jawabannya salah akan muncul kalimat "your answer is incorrect" dengan latar belakang tulisan warna merah seperti yang terlihat dalam Gambar 3.

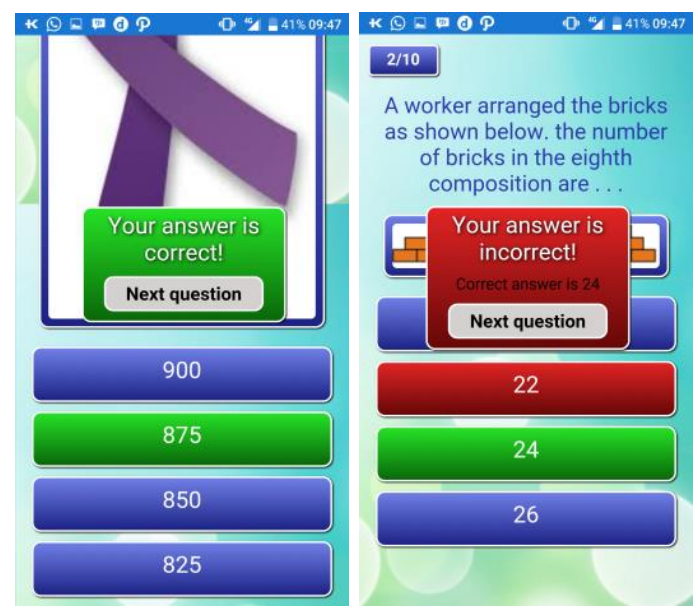

Gambar 3 Tampilan Pemberitahuan terhadap Jawaban yang dipilih

Pada tahap berikutnya, pemain dapat memilih tombol "next question" untuk menuju pertanyaan berikutnya.

Pertanyaan-pertanyaan berikutnya disusun agar tingkat kesukaran berbeda antara soal yang satu dengan soal yang lain. Namun demikian, keseluruhan soal tersebut disusun dengan memberikan gambar yang berkaitan dengan isi dari pertanyaan tersebut. Hal ini bertujuan agar tampilan game kuis ini menjadi lebih menarik. Berikut adalah gambar yang menunjukkan hal tersebut.

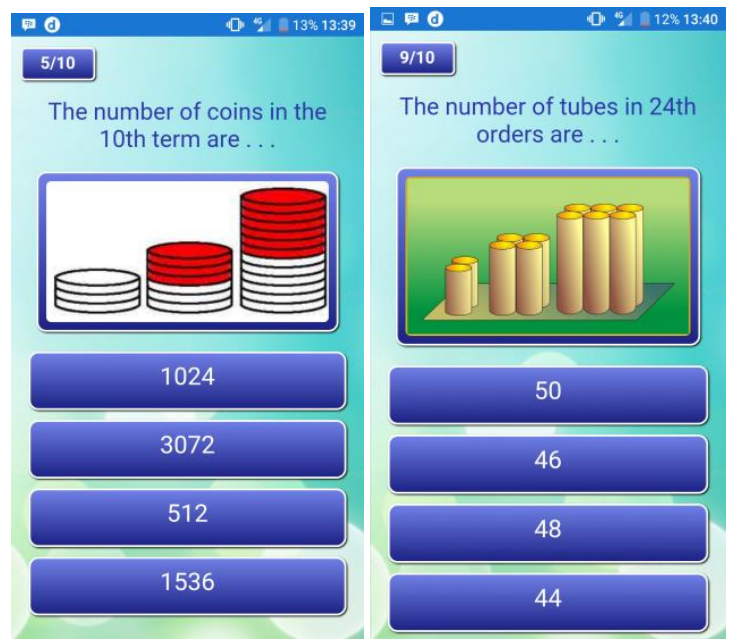

Gambar 4 Beberapa Contoh Pertanyaan

Ketika pemain sudah menyelesaikan permainan atau sudah menjawab semua pertanyaan, game ini akan menunjukkan skor yang mereka peroleh seperti yang terlihat pada Gambar 5.

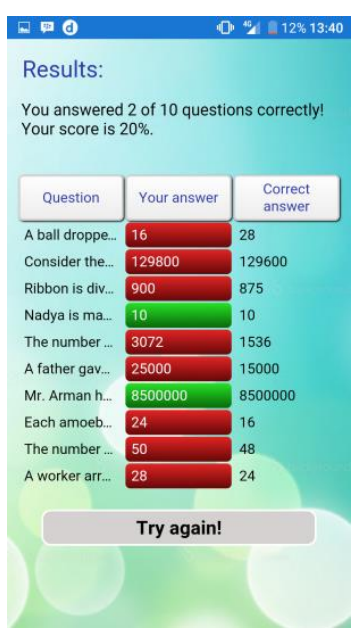

\section{Gambar 5 Skor yang diperoleh Pemain}

Berdasarkan gambar di atas, terlihat bahwa jumlah jawaban benar yang diperoleh pemain ditampilkan dalam game tersebut, yaitu dengan kata "you answered 2 of 10 questions correctly! Your score is 20\%.". Selain itu, pemain juga dapat mengetahui di soal nomor berapa saja ia menjawab dengan benar atau menjawab dengan salah.

Setelah memperoleh hasil akhir tersebut, pemain dapat menentukan apakah ingin keluar dari game atau mengulangi 
permainnannya lagi. Apabila ia ingin bermain lagi, ia dapat memilih tombol "Try Again!'.

\section{Uji Coba Produk}

Uji coba produk dalam penelitian ini terdiri dari uji ahli dan uji coba produk skala besar. Uji ahli terdiri dari valiasi media dan validasi materi. Hasil validasi media dapat dilihat pada Tabel 1.

Tabel 1. Hasil Validasi Media

\begin{tabular}{lc}
\hline \multicolumn{1}{c}{ Kriteria yang dinilai } & $\begin{array}{c}\text { Skor rata-rata } \\
\text { tiap aspek }\end{array}$ \\
\hline Aspek tampilan & 4 \\
\hline kemenarikan animasi dan gambar & 3 \\
Kesesuaian ukuran animasi, gambar, dan tulisan & 3 \\
Kesesuaian tata letak animasi, gambar, dan tulisan & 4 \\
Kesesuaian tampilan media dengan karakteristik & \\
siswa & \\
\hline Aspek tulisan & 4 \\
\hline Kemudahan tulisan untuk dibaca & 3 \\
Kemudahan kalimat untuk dimengerti & 3 \\
\hline Kesesuaian wama yang digunakan & 3,43 \\
\hline Skor Kevalidan & \\
\hline
\end{tabular}

Berdasarkan tabel di atas, dapat diketahui bahwa skor kevalidan sebesar 3,43 . Hal ini berarti bahwa game quiz yang dikembangkan valid.

Pada uji ahli materi, diperoleh skor seperti yang terlihat pada Tabel 2.

Tabel 2. Hasil Validasi Materi

\begin{tabular}{lc}
\hline \multicolumn{1}{c}{ Kriteria yang dinilai } & $\begin{array}{c}\text { Skor rata } \\
\text { rata tiap } \\
\text { aspek }\end{array}$ \\
\hline Aspek Isi & 4 \\
\hline Kesesuaian media dengan mater barisan dan deret & 3 \\
Kesesuaian konsep-konsep barisan dan deret yang disajikan dalam media & 3 \\
Kesesuaian animasi dan gambar yang ditampilikan dengan materi barisan dan deret & 4 \\
Kejelasan animasi dan gambar dalam menyampaikan permasalahan terkait banisan & 4 \\
dan deret & \\
\hline Aspek tulisan & 4 \\
\hline Kemudahan tulisan untulk dibaca & 4 \\
Kemudahan kalimat untuk dimengerti & 3 \\
Kesesuaian wama yang digunakan & 3,57 \\
\hline Skor Kevalidan &
\end{tabular}

Berdasarkan tabel di atas, diperoleh informasi bahwa nilai validitas sebesar 3,57. Hal ini berarti media dapat dikatakan valid dan siap untuk diujicobakan.
Uji coba dilakukan untuk menguji respon siswa terhadap media yang telah dikembangkan. Untuk mengetahui respon siswa tersebut, peneliti memberikan angket kepada siswa dan meminta siswa tersebut melalukan penilaian secara objektif. Penilaian tersebut didasarkan pada aspek fungsi dan desain. Hasil analisis angket respon siswa dapat dilihat pada tabel berikut.

Tabel 3. Respon Siswa

\begin{tabular}{lc}
\hline \multicolumn{1}{c}{ Kriteria yang dinilai } & $\begin{array}{c}\text { Skor rata- } \\
\text { rata tiap } \\
\text { aspek }\end{array}$ \\
\hline Aspek Desain & \\
\hline Wama, tulisan, gambar, dan animasi menarik & 3,04 \\
Kalimat yang digunakan jelas & 3 \\
Media mudah untuk dioperasikan & 3,38 \\
\hline Aspek Fungsi & 3,28 \\
\hline $\begin{array}{l}\text { Media mampu memberikan sarana belajar } \\
\text { dan berlatih materi barisan dan deret }\end{array}$ & 3,04 \\
$\begin{array}{l}\text { Media mampu memotivasi saya untuk } \\
\text { berlatih mengerjakan soal matematika }\end{array}$ & 3,148 \\
\hline Skor kevalidan
\end{tabular}

\section{PEMBAHASAN}

Berdasarkan hasil validasi dan uji coba yang telah dilakukan, dapat diketahui bahwa media pembelajaran yang dikembangkan valid. Hal ini dapat diketahui dari skor masing-masing aspek yang memperoleh nilai $\geq 3$.

Hasil uji coba skala besar menunjukkan bahwa media pembelajaran yang dikembangkan mampu memotivasi siswa dalam berlatih mengerjakan soal matematika dan mampu memberikan kesempatan bagi siswa untuk mencoba berbagai tipe soal materi barisan dan deret. Selanjutnya, dapat diketahui pula bahwa siswa memberikan respon yang positif terhadap setiap indikator/aspek yang dinilai. Hal ini memperkuat hasil penelitian yang dilakukan oleh Abidin, Marzal, dan Rohati (2014), bahwa penggunaan mobile 
learning berbasis android dapat meningkatkan motivasi belajar siswa dalam belajar matematika.

Secara umum, kelebihan media yang telah dikembangkan adalah 1) tampilan media memberikan kombinasi warna yang beragam sehingga terlihat elegan, 2) butir soal atau pertanyaan disajikan dalam bahasa inggris sehingga juga dapat meningkatkan kosakata matematika siswa dalam bahasa inggris, 3) ukuran file media pembelajaran yang tidak terlalu besar, dan 4) kompatible dengan semua versi android. Namun demikian, media yang telah dikembangkan juga memiliki beberapa kekurangan, di antaranya: 1) jumlah soal yang terbatas dan 2) tidak ada pembahasan untuk setiap soal.

\section{KESIMPULAN DAN SARAN}

Game quiz berbasis android yang dikembangkan valid dan dapat memberikan kesempatan lebih bagi siswa dalam berlatih mengerjakan soal-soal matematika. Namun demikian, media ini masih terbatas pada materi barisan dan deret. Peneliti lain dapat mengembangkan media yang sejenis dengan menggunakan materi matematika yang berbeda.

\section{DAFTAR PUSTAKA}

Abidin,, Marzal, J., dan Rohati.2014. Pengembangan Media Pembelajaran Matematika Interaktif Berbasis Android Untuk Menumbuhkan Motivasi Belajar Anak Disleksia Pada Materi Eksponensial Di Kota Jambi. Edumatika $4(2)$ : $66-76$.

Arifpurnamayana, M. I. 2012. Rancangan dan Pembuatan Mobile Learning Berbasis Android. [Online]. Diakses pada http://repository.gunadarma.ac.id.

Arsyad, A. 2015. Media Pembelajaran (Edisi Revisi). Jakarta: Rajawali Pers
Fatmawati, S. 2015. Pengembangan Mobile Learning Berbasis Android Menggunakan Adobe Flash CS6 Pada Mata Pelajaran Bahasa Inggris Untuk Meningkatkan Hasil Belajar Siswa Kelas X TKJ SMK Hidayah Semarang. Skripsi. Universitas Negeri Semarang.

Hasmiah. 2010. Meningkatkan Hasil Belajar Matematika Melalui Penerapan Asesmen Kinerja. Lentera Pendidikan, 13(1): 33-43

Kusuma, D. 2016. Pengembangan Mobile Learning Matematika Sebagai Suplemen Pembelajaran Trigonometri Siswa SMA Kelas X. Skripsi. Universitas Kristen Satya Wacana.

Maulana, L. 2017. Pengembangan Media Pembelajaran Berbasis Mobile Learning dengan Platform Android Materi Keselamatan Kesehatan Kerja dan Lingkungan Hidup (K3LH) Pada Program Studi Ketenagalistrikan untuk Siswa Sekolah Menengah Kejuruan. Program Studi Pendidikan Teknik Mekatronika 7(2): 188-207.

Purbasari, R. J. 2013. Pengembangan Aplikasi Android sebagai Media Pembelajaran Matematika pada Materi Dimensi Tiga untuk Siswa SMA Kelas X. [Online]. Diakses pada http://jurnalonline.um.ac.id/data/artikel/artikel629A 7613BF0506BACDD417F2B66AEF50 .pdf

Setyadi, D., dan Abd. Qohar. 2017. Pengembangan Media Pembelajaran Matematika Berbasis Web pada Materi Barisan dan Deret. Kreano 8(1): 1-7.

Soenarto. 2003. Metodologi penelitian pengembangan untuk peningkatan kualitas pembelajaran. Jakarta: Depdiknas

Syah, M. 2010. Psikologi Pendidikan dengan Pendekatan Baru. Bandung: ROSDA 